\title{
Recycling building materials is the ideal way to protect the environment
}

\author{
Arkadiy Larionov*, and Raheem Al-Rubaye Saba Jasim \\ Moscow State University of Civil Engineering, 129377, Moscow, Russia
}

\begin{abstract}
Annotation. At the present time, the issues of combating environmental pollution are especially acute in the world. At various scientific and public platforms, the sources of the negative impact on the environment and ways to restore the ecosystem are discussed. The purpose of this article is to consider one of the main sources of environmental pollution - construction waste. Having studied a number of works on this topic and summarizing the results obtained, the authors give a detailed description of environmentally hazardous construction waste. At the same time, the authors propose a solution to this problem, which consists in the recycling of waste, that is, in the reuse of unnecessary things for the purpose of subsequent use as raw materials, energy, materials and consumer products. The authors argue that recycling waste can be safe and profitable, with great returns. Thus, the recycling of environmentally hazardous, in this particular case, construction waste will contribute not only to solving environmental issues, but also to improve the economic situation of the state.
\end{abstract}

\section{Introduction}

The main task of construction is to create an environment suitable for human life and activities. Previously, during construction, the external impact on the built environment was taken into account, but recently the process has become reversible. Its reversibility consists in studying the impact of the built environment on the natural environment in terms of the volume of waste resulting from the demolition of buildings and structures, and waste of construction materials, where construction is the main cause affecting the environment. The impact on nature can be observed at all stages of construction, starting with the extraction and production of building materials (depletion of natural resources such as stone, sand, clay, etc.). In order to avoid the negative impact of construction waste, it is allowed to recycle, collect and reuse it. [1]

Previous research shows that building waste recycling experience ensures environmental sustainability and reduces depletion of natural resources. The stage of collecting and reusing waste is an important step in preventing an environmental disaster.

Of course, the main human task is to promote and develop construction activities, but at the same time it is necessary to preserve the environment. In this regard, it is important to understand that the processing of construction waste has two goals:

\footnotetext{
* Corresponding author: proflarionov@mail.ru
} 
1. An environmental goal that solves the problem of garbage accumulation, studies the decomposition of waste and, in addition, minimizes the depletion of natural resources.

2. The economic goal of reusing unnecessary material for its subsequent use as raw material, and, as a result, bringing in more profit. [7], [8].

\section{Environmental safety from construction waste}

Construction is one of the most dangerous sources of environmental pollution. Its negative impact affects all stages. It consists in air pollution from the use of various equipment, welding, due to emissions of gases into the atmosphere from vehicles. Due to the supply of equipment and vehicles with fuel, pollution enters the groundwater. Also, one of the most unpleasant environmental pollution is quite common - noise pollution of the environment due to the loud sound that a variety of construction equipment, vehicles and work equipment produces. More accumulation of construction waste provokes the formation of landfills in the fields and in the forest belt.

The Constitution of the Russian Federation, like any other industry, provides for certain requirements for environmental protection and the preservation of natural resources during construction activities.

The next construction in any populated area of the Russian Federation negatively affects the state of the natural environment. Therefore, the legislature had to draw up basic environmental rules, following which it would be possible to minimize the negative impact on the environment during the execution of construction work.

Environmental conditions during construction must be taken into account and strictly observed. It is necessary to exclude the likelihood of environmental pollution, as well as the preservation of the landscape, soil cover, shrubs and trees on the urban development site and its adjacent territory:

Industrial construction waste enters the environment in the form of smoke, various gases, liquid and solid waste. They are among the most dangerous substances affecting the environment. As a result, the problem of processing and disposal of construction waste has long arisen on the territory of Russia. However, until now, the solution of this issue has not received due attention. There is another equally important question: an increase in the amount of building materials produced outside of Russia. Their danger is due to the fact that the production technology and environmental characteristics of these materials are unknown. The disadvantages of using such polymeric materials have already been studied. Environmental scientists are calling for strict control over the use of building materials, as well as the raw materials used in their production. This control will help to ensure environmental safety. But at the present time, studies show that on the basis of inorganic compounds in the Russian Federation, an environmental assessment of building materials is not carried out.

Meanwhile, their uncontrolled use negatively affects human health, since the chemicals that are part of building and finishing materials and emitted into the atmosphere persist for a long period of time.

As we can see, today in the field of construction there is a huge number of tasks related to the preservation of the natural environment. Environmentally friendly construction technologies are the main issue that we must solve today. Nowadays, many methods are used in order to protect the environment when erecting new buildings and construction projects [5]

Let's list them:

- commissioning of environmentally friendly building materials;

- introduction of energy saving technologies; 
- organization of the ideal microclimate in the dwelling;

- production of economically viable communications using utilities such as gas, electricity, heating and water.

Today, in the construction business around the world, a positive direction can be noted towards the commissioning of a large number of natural materials. Chemical paints are replaced with natural dyes (lime, clay). Heaters for walls are used environmentally friendly (linen, wood, cotton, polyester). Thermal insulation materials reduce the consumption of electricity and heating devices. And instead of ordinary lamps, modern residents use energy-saving and phyto-lamps in their apartments and houses. During the construction of facilities, waste is separated and disposed of.

We can say that at present in the construction industry at various stages of construction, a number of requirements for ensuring environmental safety are distinguished:

- compliance with technologies and conditions in the field of environmental protection for the preservation of the environment, rational use and reproduction of natural resources;

- keep records of various environmental impacts after the commissioning of construction projects

- it is necessary to accurately calculate the norms of anthropogenic load on the natural environment within its acceptable limits, and try to reduce it at each stage of development planning

- do not allow developers to exclude from the budget the costs of maintaining a clean environment

- control the maintenance of documentation for maintaining the environmental health of the surrounding area

- allow the commissioning of the facility only if all the rules for preserving the landscape are observed and if it has the necessary tools and equipment that can dispose of hazardous waste

- allow the facility to be put into operation only if the necessary funds and equipment are available on it and reduce harmful emissions into the atmosphere

- after decommissioning the facility, it is necessary to take care in advance that any area of the natural environment that could be disturbed can be restored. [3], [6].

\section{Environmentally hazardous waste}

The garbage problem is one of the most serious problems of the present and future. Just 100 years ago, mankind had no idea that garbage would become a global problem on a planetary scale in the future. Humanity produces more than 3.5 million tons of solid waste every day. And with the growth of the population, this figure will increase. Therefore, the issue of waste recycling has become relevant. Especially the issue of processing hazardous waste that negatively affects both human health and the environment in general.

Which waste are considered harmful and hazardous? These are, first of all, poisonous, explosive and flammable elements and substances that can cause irreparable damage to flora and fauna. Radioactive waste hazardous to both humans and the health of the natural environment. As well as materials containing the threat of the spread of bacterial and viral infections. [2]

Organizations cannot accept hazardous waste for reuse or disposal without special documentary permission. This does not apply to enterprises with a specific specialization in the processing or supply of hazardous waste, such as medical organizations. Hazardous waste should be disposed of according to clearly regulated sanitary standards and lists. Violation of these rules and regulations can result in severe fines. Before disposal, hazardous waste should be classified into classes [6].

Class 1 includes industrial wastes that are extremely hazardous to the environment, 
destroying it on the scale of a catastrophe. These are any mercury-containing objects, fluorescent lamps, galvanic cells, such must be disposed of in conditions of rigid isolation.

Class 2 includes waste that is highly hazardous. After their negative impact, the ecological environment can recover for more than 30 years. These are electrolyte batteries, out-of-service cells that contain copper chloride or antimony trioxide.

Class 3 - it is a moderately hazardous waste for the environment. It will take about 10 years to restore the ecosystem after exposure to such wastes. These are motor oils, oil waste, harmful varnishes and chemical dyes.

Class 4- these are low-hazard waste (construction and household waste, such as: putty, brick, fittings, crushed stone, old furniture, garbage from the streets, chalk, etc.). Recovery from this type of pollution has been going on for 3 years.

Class 5 includes the least hazardous to humans or the environment wastes. These are paper, wood, biological waste, shavings, ash, sawdust, chips, shells.

\section{Terms of decomposition of garbage and waste}

The trash and household waste generated by the inhabitants of the planet every day accumulates and pollutes it. The time of their decomposition varies from a couple of days to tens of centuries. It all depends on the origin of this waste, as well as the classification. Including the period of disappearance of waste depends on the environment in which this waste is collected (open air, soil, water, or in a closed landfill). Pay attention to Fig. 1. [9]

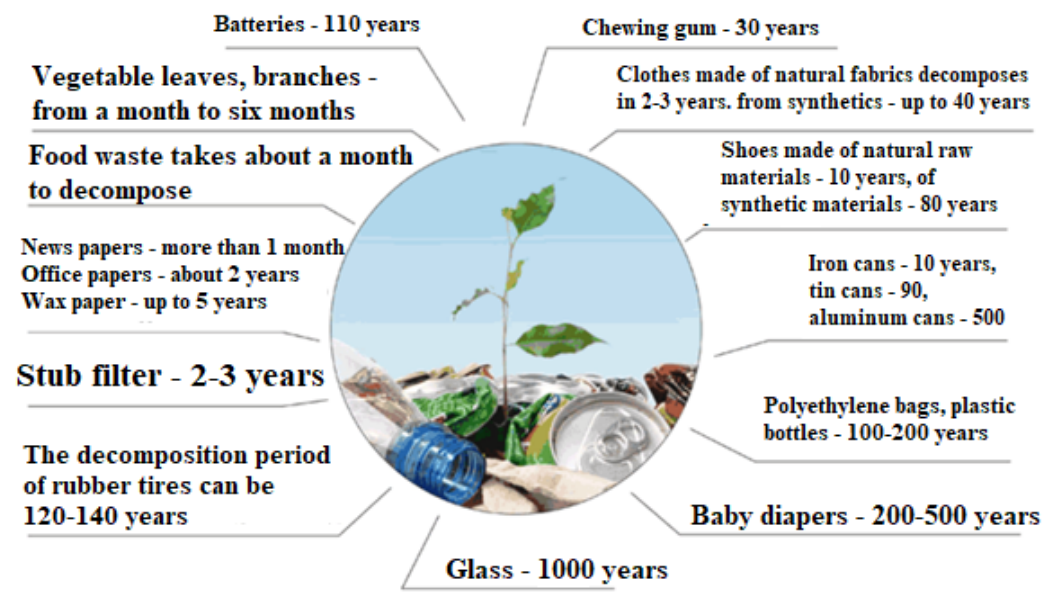

Fig. 1. Terms of decomposition of garbage and waste

Let us consider the characteristics of the decay of a number of materials in more detail.

- $\quad$ Plastic. One of the most common materials in modern life. Humanity uses about 1.6 million barrels of oil annually to produce plastic water bottles alone. It takes too long to decompose plastic waste. Decomposition of plastic products occurs at different rates depending on its composition. The first to rot are plastic bags - about 100 years in the soil. Products made of polypropylene will smolder for at least 500 years. (The Great Pacific Garbage Patch is hundreds of kilometers of accumulated plastic.)

- Aluminum. Its decomposition period is more than 500 years. It is by far the longest-lasting malicious item on the planet. 
- Glass. It is relatively easy to recycle because it is made from sand, which is a natural material. By melting a glass product, new glass can be produced many times. And if glass is not recycled, then it may not decompose in a million years.

- $\quad$ Paper waste. The decomposition of this material takes little time. The smoldering of a thin newspaper lasts three to four months. Heavier paper, such as magazines, takes much longer to decompose, about several years.

- $\quad$ Cardboard products take three to four months to decompose.

- Building materials (for an illustrative example, you can wander around abandoned houses)

- $\quad$ Brick and concrete: they take over a hundred years to decompose, with brick and concrete gradually crumbling.

- $\quad$ Reinforcement bars will decompose approximately 12 years after being disposed of in a landfill.

- Boards: can rot for decades if not stored properly. There is a danger that a lot of insect pests can start in the boards, which accelerate the decomposition time and can move into residential buildings and apartments.

- $\quad$ Leaves, seeds and branches of trees smolder up to four months.

- If every inhabitant of our Earth takes responsibility for the separate collection of their own garbage, then the problem of global pollution of the environment and atmosphere, as well as the formation of illegal dumps, may eventually disappear. [7]

- There is already a positive trend in plastic recycling in the world. Many designers make clothes from plastic bottles, in Russia they build children's wheelchairs from plastic "good" caps, and the British artist Richard Sowa has built a whole private island in the Caribbean made of plastic bottles!

\section{Conclusion}

1. The main regulatory factor that should ensure environmental safety should be the new rules in the field of environmental protection, prescribed in the Constitution of the Russian Federation, which will have to be observed by all construction companies and contractors, without exception. Creation of nanotechnological equipment that will be able to calculate the level of environmental health and the degree of threat to the environmental situation on the territory of the facility being erected. Creation of a recycling station at each construction complex and ways of sending waste waste to recycling plants.

2. The country's economy should be foreseen in the costs of reducing environmental pollution. As well as an increase in liability for violations, providing for an increase in the size of fines imposed on organizations that allow emissions of harmful substances.

A discipline such as ecology should become mandatory not only in higher and secondary specialized educational institutions, but also in schools.

\section{References}

1. S.P. Oleinik, Construction waste during the reconstruction of buildings and structures, Internet magazine. "Waste and Resources" 2, 2 (2016)

2. A.N. Ryazantsev, A.L. Lysenko, N.G. Rybalsky, V.V. Aleksashina, A.N. Tetior, E.D. Samotesov, V.V. Gorbatovsky, I.V. Ignatovich, Ecological safety in the building complex (NIA-Priroda, Moscow, 1999)

3. https://proektportal.ru/6450071621/blog/127. (date of access: 02.09.2020). 
4. Federal Law of 10.01.2002 N 7-FZ (as amended on 29.07.2017) "On environmental protection".

5. N.V. Gusakova, A.I. Zabalueva, V.V. Rumyantseva, Ecology. Lecture notes (Ed. A. N. Korolev, Publishing house TRTU, Taganrog, 2006)

6. K.M. Emelianenko, Ensuring the environmental safety of construction, Young scientist, 5 (191), 20-22 (2018)

7. https://promusor.info/pererabotka/vtorichnoe-ispolzovanie-othodov/ (date accessed: 17.09.2020).

8. T.G. Klyueva, A.N. Larionov, Management of green housing construction: a regional aspect (Research Center "Strategy". MAKS Press, Moscow, 2010)

9. https://stop-othod.ru/recycling/skolko-let-razlagaetsya-musor.html. (date of access: 17.09.2020). 